\title{
Redescription of Notarius grandicassis and Notarius parmocassis (Siluriformes; Ariidae), with insights into morphological plasticity and evidence of incipient speciation
}

Alexandre P. Marceniuk, Raquel Siccha-Ramirez, Ronaldo Borges Barthem \& Wolmar Benjamin Wosiacki

To cite this article: Alexandre P. Marceniuk, Raquel Siccha-Ramirez, Ronaldo Borges Barthem \& Wolmar Benjamin Wosiacki (2017) Redescription of Notarius grandicassis and Notarius parmocassis (Siluriformes; Ariidae), with insights into morphological plasticity and evidence of incipient speciation, Systematics and Biodiversity, 15:3, 274-289, DOI: 10.1080/14772000.2016.1256916

To link to this article: https://doi.org/10.1080/14772000.2016.1256916

+ View supplementary material $\widetilde{ }$

Submit your article to this journal $\pi$
Published online: 05 Jan 2017.

山 Article views: 79 


\title{
Research article
}

\section{Redescription of Notarius grandicassis and Notarius parmocassis (Siluriformes; Ariidae), with insights into morphological plasticity and evidence of incipient speciation}

\author{
ALEXANDRE P. MARCENIUK ${ }^{1,2}$, RAQUEL SICCHA-RAMIREZ ${ }^{3,4}$, RONALDO BORGES BARTHEM $^{1}$ \& WOL- \\ MAR BENJAMIN WOSIACKI ${ }^{1}$ \\ ${ }^{1}$ Museu Paraense Emílio Goeldi, 6604-170, Belém, PA, Brazil \\ ${ }^{2}$ Acervo Zoológico, Universidade Santa Cecília, 11045-907, Santos, SP, Brazil \\ ${ }^{3}$ Laboratorio de Biologia e Genética de Peixes, Instituto de Biociencias, UNESP, 18618-689, Botucatu, SP, Brazil \\ ${ }^{4}$ Laboratorio Costero de Tumbes, Instituto del Mar del Peru, Tumbes, Perú
}

(Received 25 April 2016; accepted 5 October 2016)

\begin{abstract}
The Thomas sea catfish is characterized by a highly variable parietosupraoccipital process, which has been recognized as intraspecific variation or phenotypic plasticity. On the basis of this variation, three nominal species have been described, with two of them currently considered to be junior synonyms. Here, the Notarius grandicassis species complex is reviewed, considering the geographic variation of its morphological traits. Notarius grandicassis from north-eastern South America, and Notarius parmocassis, from eastern and southern Brazil, are redescribed as distinct evolutionary units, even though they are not differentiated by partial sequences of the mitochondrial genes CytB and ATPase 8/6. This condition is interpreted as a consequence of the recent evolutionary history of these species, which are found in distinct geographic areas with different environmental conditions.
\end{abstract}

Key words: Atlantic South America, incipient speciation, morphological plasticity, Notarius grandicassis, Notarius parmocassis

\section{Introduction}

The Thomas sea catfish, Notarius grandicassis (Valenciennes, 1840), is known to range between Barranquilla, Colombia, and the western Atlantic coast of Brazil (Figueiredo \& Menezes, 1978; Mejía-Ladino, BetancurR, Acero, \& Zarza, 2002; Taylor \& Menezes, 1977). The species can be easily differentiated from all other Neotropical ariids by its thick upper lip, relatively long and pointed snout, which is projected forward from the ventral mouth, and the parietosupraoccipital process, which is invariably constricted at the base (Marceniuk, 2005a; Mejia-Ladino et al., 2002). This species is very common along the northern coast of South America, where it is caught by artisanal fisheries and as bycatch in shrimp trawls, but it is much rarer on the eastern and southern coasts of Brazil (Betancur-R, Marceniuk, Giarrizzo, Fredou, \& Knudsen, 2015). Despite its abundance on the

Correspondence to: Alexandre P. Marceniuk. E-mail: a_marceniuk@hotmail.com north-eastern coast of South America, the behaviour and biology of the species are unknown (Betancur-R. et al., 2015; Le Bail, Keith, \& Planquette, 2000).

Fish species identification is traditionally based on features of external morphology, such as body shape, colouration patterns, configuration of the fins, scale and ray counts, and measurements of bodily dimensions (Strauss \& Bond, 1990). However, morphological features may have limited value for the identification of species when intraspecific, ontogenetic or sexual variation is overlooked or when the differences between species are small. The identification of ariid species is especially problematic due to the very similar external appearance of most forms, although qualitative and morphometric features of the skull provide important guidelines for species recognition (Marceniuk, 2005b, 2007; Marceniuk \& Betancur-R, 2008; Marceniuk, Betancur-R, \& Acero, 2009, Marceniuk, Menezes, \& Britto, 2012).

Differences in the configuration of the parietosupraoccipital process (Fig. 1-4) were used to support the original description of Arius grandicassis from Guyana, Arius 


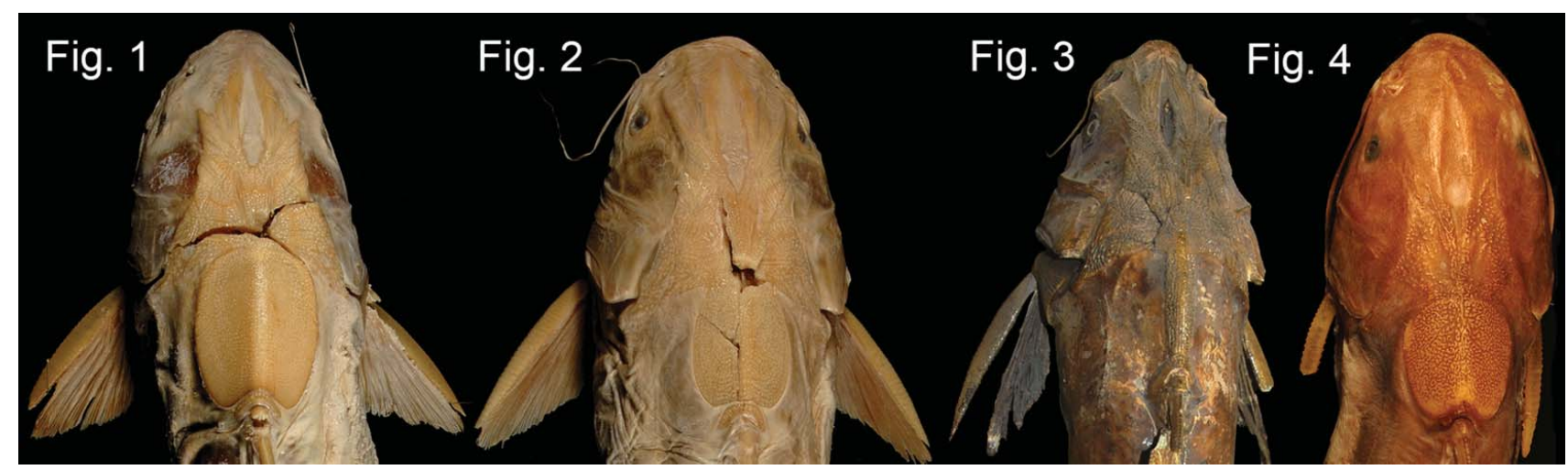

Figs. 1-4. Head in dorsal view. 1. Notarius grandicassis, holotype, MNHN A-4608. 2. Notarius parmocassis, holotype, MNHN A-8966. 3. Arius stricticassis, holotype, MNHN A-9406. 4. Arius vandeli, holotype, MNHN 1936-0160.

parmocassis Valenciennes, 1840 from Bahia, Brazil, and Arius stricticassis Valenciennes, 1840 from Cayenne, in French Guiana and Suriname, while Puyo (1936) based the description of Arius vandeli, from the Cayenne River in French Guiana, on the configuration of the accessory tooth plates. Taylor and Menezes (1977) interpreted these differences as intraspecific variation or phenotypic plasticity, considering the nominal species to be junior synonyms of Notarius grandicassis. While this arrangement has not been challenged systematically, different authors have either referred to the existence of more than one valid species in the Notarius grandicassis complex (Cervigón, 1991, Cervigón et al., 1992) or recognized population-level differences in the size of the head, adipose fin, and snout (Mejia-Ladino et al., 2002).

The present study reviews the definition of the Notarius grandicassis species complex based on the geographic variation of morphological traits, considering differences related to sex and ontogenetic stages.

\section{Materials and methods}

\section{Study area}

Considering the role of climatological and oceanographic factors in patterns of biodiversity (Amaral \& Jablonzki, 2005), five distinct regions were recognized on the Brazilian coast for the purposes of the present study: (i) the northern coast, between the mouth of the Oiapoque River $\left(4^{\circ} \mathrm{N}\right)$ in the state of Amapá and the mouth of the Parnaíba River $\left(3^{\circ} \mathrm{S}\right)$ in Maranhão, (ii) the north-eastern coast, between the Parnaíba and Todos os Santos Bay $\left(13^{\circ} \mathrm{S}\right)$ in Bahia, (iii) the eastern coast, between Todos os Santos Bay and the Cape of São Tomé $\left(22^{\circ} \mathrm{S}\right)$ in the state of Rio de Janeiro, (iv) the south-eastern coast, between São Tomé and the Cape of Santa Marta $\left(28^{\circ} \mathrm{S}\right)$ in Santa Catarina, and (v) the southern coast, between Santa Marta and the Chuí River $\left(34^{\circ} \mathrm{S}\right)$ in Rio Grande do Sul (sensu Ekau $\&$ Knoppers,1999). The region between the mouth of the Orinoco River $\left(8^{\circ} \mathrm{N}\right)$ in Venezuela, and French Guiana $\left(4^{\circ} \mathrm{N}\right)$, dominated by the plume of the Amazon and Orinoco rivers, is considered to be contiguous with the northern coast of Brazil.

\section{Distribution and biological data}

Data on the distribution of the species on the Atlantic coast of South America were obtained from the catalogues of the zoological collections available from the Neodat (http:// www.mnrj.ufrj.br/search.htm), SpeciesLink (http://www. splink.org.br/), and FishNet (www.fishnet2.net.) projects, as well as the ichthyological collection at the Goeldi Museum (Museu Paraense Emílio Goeldi: MPEG). Data on the biology, distribution, and abundance of Notarius grandicassis in the Amazonian estuary are based on Mendes and Barthem (2010). Data on the distribution and abundance of Notarius parmocassis on the southern coast of Brazil were derived from data collected by the first author in collaboration with Castro (2000) and João Luiz Rosetti Gasparini from the Federal University of Espírito Santo.

\section{Morphological analyses}

The analysis of the morphological variation in the Notarius grandicassis species group was based on the morphometric, meristic, and osteological characters of the skull and pectoral girdle. Forty-seven measurements were taken from 51 specimens, following the diagnostic approach of Marceniuk (2007). Meristic counts were made of the anal fin rays and the rakers of the first and second gill arches. Quantitative measurements were taken using either a ruler (to the nearest millimetre) or dial calipers (precision of $0.1 \mathrm{~mm}$ ). The data were analysed using XLStat (Microsoft Excel), following the log-transformation of the co-variance matrix. Variables that were constant were excluded from the PCA. Osteological characters were evaluated qualitatively in all the specimens examined, and a further eight skeletonized specimens, as well as images available in the literature. The term 'nuchal plate' refers to the fusion of the anterior and medial nuchal plates. 
The specimens examined for the morphological analysis were obtained from the zoological collections of Santa Cecília University, Santos, Brazil (AZUSC), the California Academy of Sciences, San Francisco, USA (CAS), the Palaeontological Institute and Museum of the University of Zürich (PIMUZ), the Natural History Museum of the Federal University of Alagoas, Maceió, Brazil (MNHUFAL), the National Museum, Rio de Janeiro, Brazil (MNRJ), the Zoology Museum of the University of São Paulo, Brazil (MZUSP), the Goeldi Museum, Belém, Brazil (MPEG), and the National Museum of Natural History at the Smithsonian Institution, Washington DC, USA (USNM), as well as the ichthyological collection at the Federal University of Espírito Santo in Vitória, Brazil (CIUFES).

\section{DNA extraction, PCR, and sequencing}

A small piece of tissue was collected from seven fishes, and preserved in $95 \%$ ethanol until the extraction of the
DNA. Total DNA was obtained using a DNeasy Blood and Tissue kit (Qiagen, Hilden, Germany) following the manufacturer's instructions. Two mitochondrial genes, ATP 6/8 Synthase (ATPase 6/8; 698 bps) and Cytochrome b (CytB; 976 bps), were sequenced by Polymerase Chain Reaction (PCR) in a $12.5 \mu \mathrm{L}$ reaction volume containing $1.25 \mu \mathrm{L}$ of $10 \times$ PCR buffer, $0.25 \mu \mathrm{L}$ of $\mathrm{MgCl}_{2}(50 \mathrm{mM})$, $0.2 \mu \mathrm{L}$ of dNTPs $(2 \mathrm{mM}), 0.5 \mu \mathrm{L}$ of each primer $(5 \mu \mathrm{M})$, $0.1 \mu \mathrm{L}$ of $1.25 \mathrm{U}$ Taq platinum DNA polymerase, and $1 \mu \mathrm{L}$ of the DNA template (200 ng). The PCR cycling was conducted using the following protocol: $94^{\circ} \mathrm{C}$ for $5 \mathrm{~min}$; 30 cycles of $94^{\circ} \mathrm{C}$ for $40 \mathrm{~s}, 50-56^{\circ} \mathrm{C}$ for $30 \mathrm{~s}, 72^{\circ} \mathrm{C}$ for $1 \mathrm{~min}$, and $72^{\circ} \mathrm{C}$ for $8 \mathrm{~min}$, using the primers described in Siccha-Ramirez, Menezes, Nirchio, Foresti, and Oliveira (2014). The PCR products were visualized in a $1 \%$ agarose gel and purified using ExoSAP-IT (USB Europe $\mathrm{GmbH}$, Staufen, Germany) at $37^{\circ} \mathrm{C}$ for $60 \mathrm{~min}$ followed by $15 \mathrm{~min}$ at $80^{\circ} \mathrm{C}$. The sequencing reactions were conducted using a BigDye Terminators Cycle Sequencing kit (Applied Biosystems, CA, USA) according to the

Table 1. Genbank number of the sequences used and added in the present study. The sequences generated in the present study are marked with an asterisk.

\begin{tabular}{|c|c|c|}
\hline Species & Sampling location & Genbank number ATP6/8/Cytb \\
\hline Gogo arcuatus & MG & FJ013144 / FJ013160 \\
\hline Galeichthys ater & South Africa & FJ013145 / FJ013161 \\
\hline Galeichthys feliceps & South Africa & FJ013146 / FJ013175 \\
\hline Galeichthys peruvianus & Perú & DQ990634 / DQ990462 \\
\hline Amphiarius rugispinis & Guyana & AY688655 / AY688668 \\
\hline Sciades troschelii & Panama & AY688656 / AY688669 \\
\hline Aspistor quadriscutis & Guyana & AY688657 / AY688670 \\
\hline Notarius lentiginosus & Panama & FJ625888 / FJ626171 \\
\hline Notarius armbrusteri & Colombia & DQ373042 / DQ373046 \\
\hline Notarius armbrusteri & Colombia & DQ373041 / DQ373045 \\
\hline Notarius biffi & eastern Pacific & AY688654 / AY688667 \\
\hline Notarius bonillai & Colombia & AY582863 / AY582861 \\
\hline Notarius cookei & Panama & AY582862 / AY582860 \\
\hline Notarius grandicassis & Colombia & AY688658 / AY688671 \\
\hline Notarius grandicassis & Venezuela & DQ 996637 \\
\hline Notarius grandicassis ${ }^{*}$ & Pará, Brazil & KX184204 / KX099394 \\
\hline Notarius grandicassis ${ }^{*}$ & Pará, Brazil & KX184205 / KX099395 \\
\hline Notarius grandicassis ${ }^{*}$ & Pará, Brazil & KX184206 / KX099396 \\
\hline Notarius grandicassis $^{*}$ & Pará, Brazil & KX184207 / KX099397 \\
\hline Notarius grandicassis ${ }^{*}$ & Pará, Brazil & KX184208 / KX099398 \\
\hline Notarius insculptus & eastern Pacific & AY688653 / AY688666 \\
\hline Notarius kessleri & Panama & AY688650 / AY688663 \\
\hline Notarius aff. kessleri & Colombia & FJ625885 / FJ626170 \\
\hline Notarius neogranatensis & Colombia & AY688649 / AY688662 \\
\hline Notarius parmocassis ${ }^{*}$ & Alagoas, Brazil & KX184209 / KX099399 \\
\hline Notarius parmocassis* & Espito Santo, Brazil & KX184210 / KX099400 \\
\hline Notarius planiceps & Panama & AY688651 / AY688664 \\
\hline Notarius aff. planiceps & El Salvador & AY688652 / AY688665 \\
\hline
\end{tabular}


manufacturer's instructions. The labelled sequences were assessed using an ABIPRISM 3130 Genetic Analyzer (Applied Biosystems, CA, USA). Bidirectional sequence 'contigs' were assembled, and aligned using Genious v.5.6 (Kearse et al., 2012) to obtain consensus sequences and check for indels or stop codons. Genetic distances between and within species were calculated using the Kimura 2-parameter (K2P) substitution model (Kimura 1980) and the divergence patterns suggested by these distances were represented graphically using a Neighborjoining (NJ) bootstrap tree with 1000 replicates, run in MEGA v5.0 (Tamura et al., 2011). The sequences were deposited in GenBank under the accession numbers shown in Table 1.

\section{Results}

The molecular analyses revealed the absence of genetic differentiation (Fig. 5) between the two morphologically distinct species (Fig. 6) that belong to the Notaris grandicassis species complex (sensu Cervigón, 1991; Cervigón et al., 1992; Taylor \& Menezes, 1977). Notarius grandicassis from north-eastern South America (Figs 1, 3-4, 79) and Notarius parmocassis from the eastern and southern coast of Brazil (Figs 2, 10) can be differentiated based on their morphometric indices (Fig. 11-13), morphology of the gas bladder (Fig. 14-19), and the pectoral girdle (Fig. 20-25). The analysis of the morphological characters employed in the original descriptions of the species

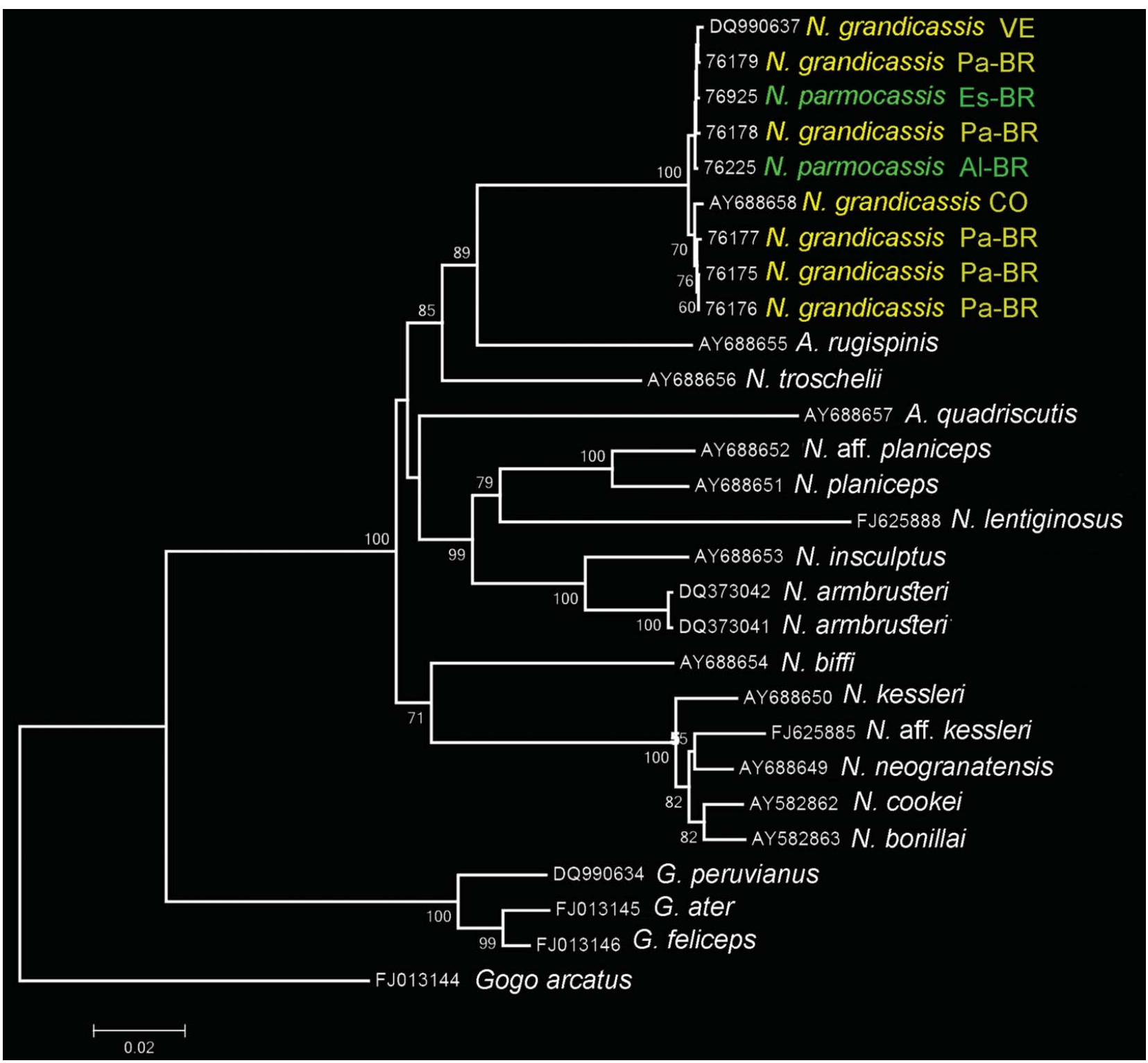

Fig. 5. Neighbor-Joining tree obtained from the CytB and ATPase data. Numbers at the branches represent bootstrap values obtained from 1000 pseudoreplicates. 


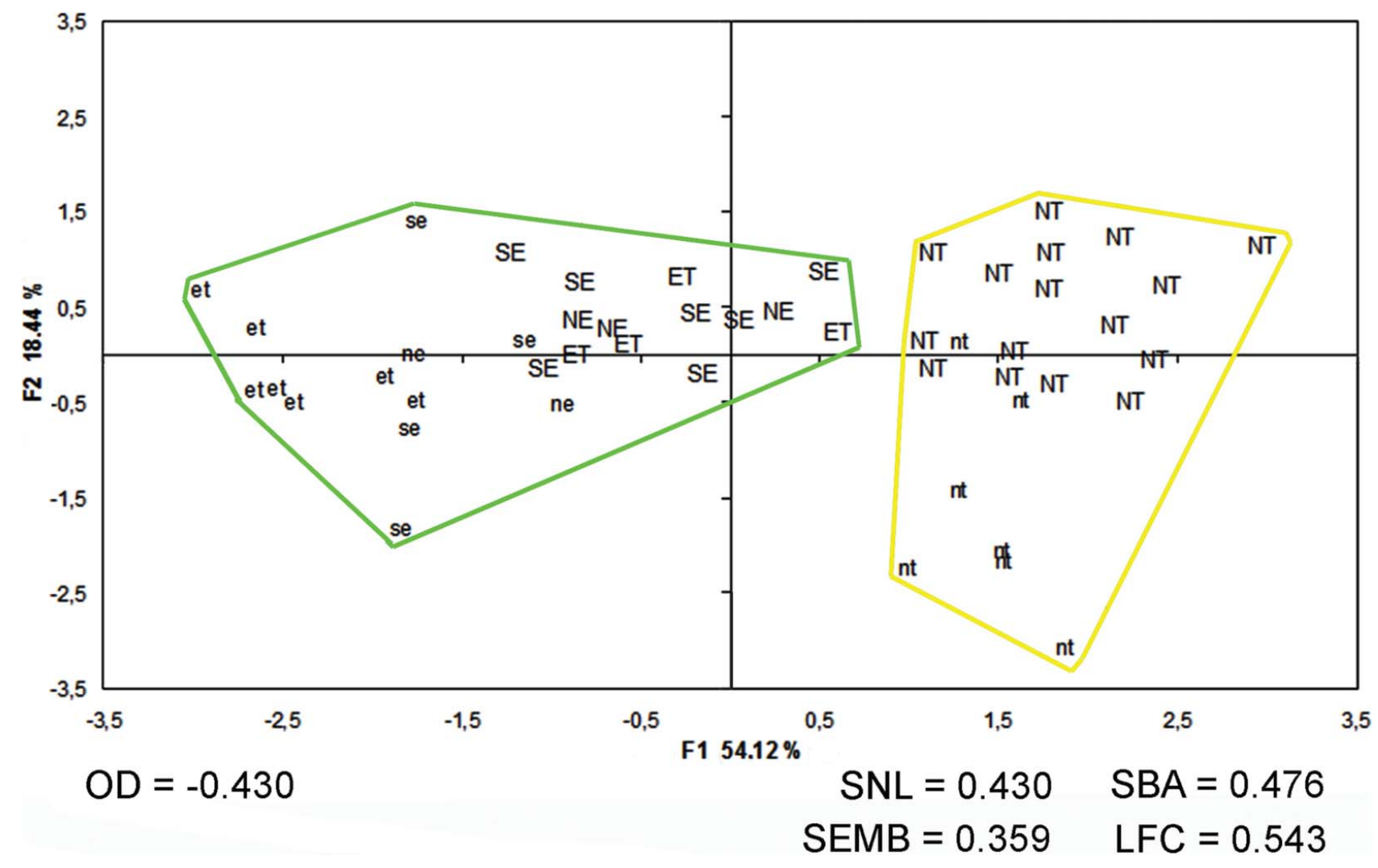

Fig. 6. Scatterplots of the principal components (PC1 and PC2), obtained from the analysis of three morphometric, one meristic, and one qualitative variables for Notarius grandicassis (northern coast, NT - specimens larger than $250 \mathrm{~mm}$ SL, nt - specimens smaller than $250 \mathrm{~mm} \mathrm{SL}$ ) and Notarius parmocassis (north-eastern coast: NE - specimens larger than $250 \mathrm{~mm}$ SL, ne - specimens smaller than $250 \mathrm{~mm}$ SL; eastern coast: ET - specimens larger than $250 \mathrm{~mm} \mathrm{SL}$, et - specimens smaller than $250 \mathrm{~mm}$ SL; south-eastern coast: SE specimens larger than $250 \mathrm{~mm} \mathrm{SL}$, se - specimens smaller than $250 \mathrm{~mm} \mathrm{SL}$ ). OD, orbital diameter; SNL, snout length; SEMB, distance from snout to external mental barbel; LFC, lateral face of cleithrum; SBA, number of gill rakers on second branchial arches.

(Valenciennes, 1840) revealed that they are plastic traits (Fig. 26-32), presenting distinct patterns of variation in Notarius grandicassis (Fig. 29-30) and Notarius parmocassis (Fig. 31-32), and at different stages of ontogenetic development (Figs 30, 32, 33-35).

The absence of any significant genetic differentiation between Notarius grandicassis and Notarius parmocassis species are the result of a recent speciation process, resulting from occurrence of the species in different geographic areas with distinct environmental conditions and selective pressures (da Silva et al., 2016), in the Atlantic Ocean of South America (Fig. 36). This conclusion is also supported by the plastic characters, which present distinct patterns of variability in Notarius grandicassis (Fig. 2930) and Notarius parmocassis (Fig. 31-32).

\section{Taxonomic description}

Notarius grandicassis (Valenciennes, 1840)

Thomas sea catfish, English; Bagre currulao, Spanish; Cambéua, Portuguese
(Figs 1, 3-4, 7-9, 14-16, 20-22, 29, 37; Table S1, see online supplemental material, which is available from the article's Taylor \& Francis Online page at http://dx.doi.

org/10.1080/14772000.2016.1256916; Table 2.)

Arius grandicassis Valenciennes in Cuvier and Valenciennes, 1840: 54, Pl. 427 [original description, Guyana]. Arius stricticassis Valenciennes in Cuvier and Valenciennes, 1840: 58 [original description, Cayenne, French Guiana, Suriname]. Arius vandeli Puyo, 1936: 123, Figs 21G, 22 [original description, Cayenne River, French Guiana].

Diagnosis. Notarius grandicassis is distinguished from all other Neotropical ariids, except $N$. parmocassis, by a parietosupraoccipital process with a constriction at the base (vs. without a constriction at the base in all other Ariidae, Figs 1, 3-4); cleithrum posterior process indistinct ( $v s$. very conspicuous in all other Ariidae, except Galeichthys, Fig. 20-22); pectoral-fin spine very depressed, with its height at least three times its width (vs. slightly to moderately depressed, always less than three times the width in 


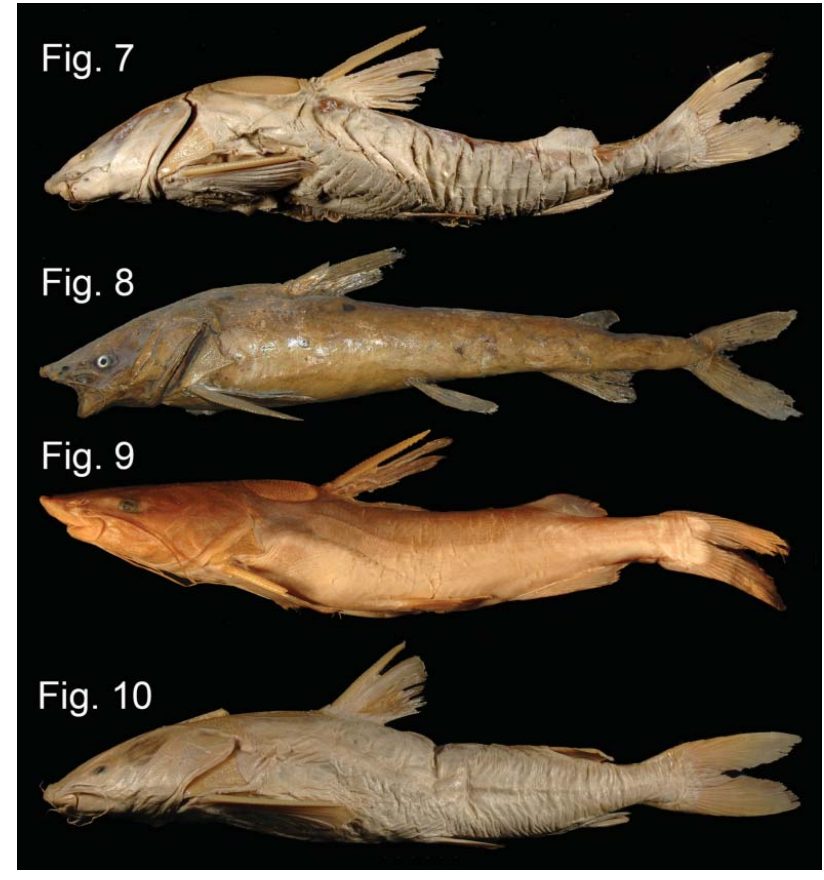

Figs. 7-10. Body in lateral view. 7. Notarius grandicassis, holotype, MNHN A-4608. 8. Arius stricticassis, holotype, MNHN A-9406.9. Arius vandeli, holotype, MNHN 1936-0160. 10. Notarius parmocassis, holotype, MNHN A-8966.

all other Ariidae); gas bladder with two chambers (vs. a single chamber in all other Ariidae, or three chambers in Sciades proops and S. parkeri, Fig. 14-16).

Notarius grandicassis is distinguished from Notarius parmocassis by a combination of osteological, morphometric, and meristic characters (Fig. 6). Notarius grandicassis differs from Notarius parmocassis by having 17-19 or rarely 16 gill rakers on the second arch (vs. 14-16, rarely 17, Table 2); orbital diameter 3.5-4.4 times snout length (vs. 2.4-3.4, rarely 3.5, Fig. 11); lateral face of cleithrum very wide, with straight posterior profile between second dorsal process and posterior process (vs. moderately wide, smoothly convex or angled, Fig. 20 $25)$. Juveniles and smaller specimens ( $\mathrm{SL}<250 \mathrm{~mm}$ ) of Notarius grandicassis can be differentiated by the relatively longer snout, 9.7-11.0\% SL (vs. 8.0-9.6\%, Fig. 12), and the anterior chamber of the gas bladder, which is as wide as it is long, with posterior edge pointed ( $v s$. wider than long, with a rhomboid edge, Fig. 14-19), whereas the orbital diameter in the adults, or specimens longer than $250 \mathrm{~mm} \mathrm{SL}$, is 3.3-4.1 the distance from the snout to the base of the external mental barbel (vs. 2.9-3.2, Fig. 13), and the posterior chamber of the gas bladder is longer than the preceding chamber ( $v s$. shorter than the preceding chamber, Fig. 14-19).

Material examined. PIMUZ uncatalogued (8, 255$567 \mathrm{~mm} \mathrm{TL}$ ), Gulf of Venezuela, Venezuela; USNM
$206981(1,285 \mathrm{~mm} \mathrm{SL}), 10^{\circ} 48^{\prime} \mathrm{N}, 62^{\circ} 35^{\prime} \mathrm{W}$, Venezuela; USNM 233860 (1, $245 \mathrm{~mm} \mathrm{SL})$, mouth of Orinoco River, Venezuela; USNM 66249 (1, 345 mm SL), Georgetown Market, Guyana; USNM 66248 (1, 380 mm SL), British Guyana; USNM 215966 (1, 215 mm SL), French Guiana; MNRJ 20617 (1, 445 mm SL), Amapá, Brazil; MPEG 3548 (1, 330 mm SL), Amazon estuary, Pará, Brazil; MZUSP 116075 (5, 184-348 mm SL), Salinas, Pará, Brazil; AZUSC 4576 (2, 193-204 mm SL), Salinas, Pará, Brazil; MPEG 33703 (3, 289-334 mm SL), Salinas, Pará, Brazil; MPEG 33704 (8, 314 423 mm SL), Salinas, Pará, Brazil; AZUSC 4573 (1, 407 mm SL), Salinas, Pará, Brazil; MPEG 30618 (2, 231-241 mm SL), Bragança, Pará, Brazil. MPEG 30647 (1, 450 mm SL), Bragança, Pará, Brazil.

\section{Description}

Morphometric data. Summarized in Table S1 (see supplementary material online).

Head. Head long, moderately wide and markedly depressed in lateral ethmoid area; profile slightly elevated posteriorly, straight from mesethmoid to parietosupraoccipital, sometimes markedly convex in parietosupraoccipital area. Snout long and sharp anteriorly. Anterior nostril round, with fleshy edge; posterior nostril covered by flap of skin; nostrils distant from one another and distant from orbit; unconnected by fleshy furrow. Eyes lateral, small and distant from one another. Three pairs of long teretiform barbels; maxillary barbel surpassing or almost reaching posterior margin of gill membrane, lateral mental barbel reaching or not posterior margin of gill membrane, and mesial mental barbel falling shy of posterior margin of gill membrane.

Mouth, tooth plates and gill rakers. Mouth inferior and wide, with lower jaw pronouncedly arched. Lips thick, upper lip thickest. Vomerine tooth plates absent or present. Accessory tooth plates triangular, with or without posterior plates, and sharp teeth. Premaxilla moderately long and wide, with sharp teeth. Dentary tooth plates separated at midline, with sharp teeth. Gill membranes fused together and attached to isthmus. Thirteen to 16 acicular gill rakers on first arch, 16-18 spike-shaped gill rakers on second arch.

Neurocranium. Cephalic shield exposed, long and wide in lateral ethmoid area, moderately wide in frontal and supracleithrum areas, with thick granulation irregularly distributed or thin granulation uniformly distributed. Osseous bridge formed by lateral ethmoid and frontal relatively long and slender, delimiting moderately large fenestra, evident under skin. Fleshy dorsomedial groove of neurocranium evident at level of mesethmoid to frontal, with posterior 

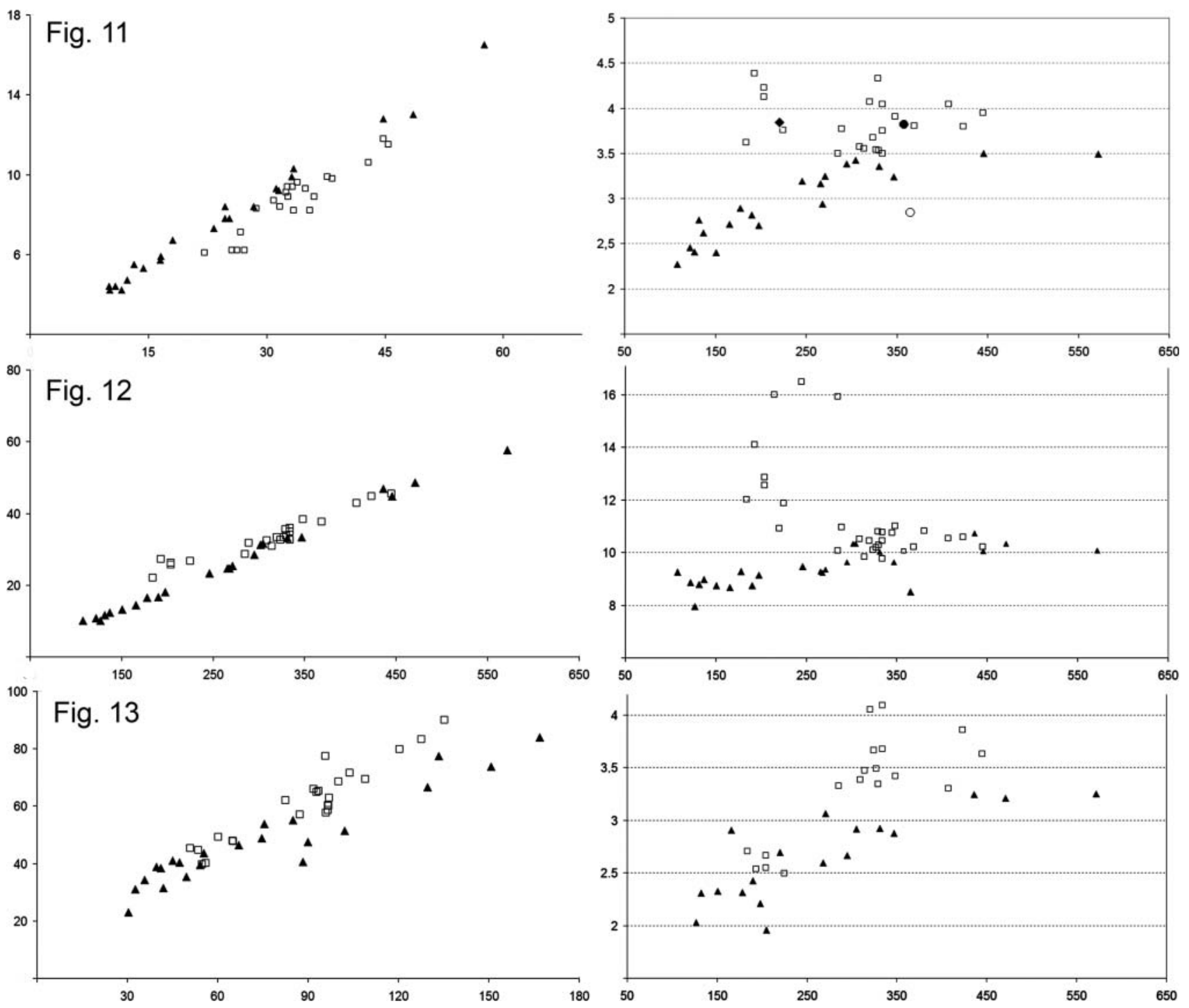

Figs. 11-13. Plots of the morphometric traits (left) and the relationship between morphometric indices and the standard length (right) in Notarius grandicassis (open squares) and N. parmocassis (solid triangles). 11. Orbital diameter vs. snout length, holotype of Notarius grandicassis (solid circles), holotype of N. parmocassis (open circles), and holotype of Arius vandeli (solid trapeze). 12. Snout length vs. standard length. 13. Orbital diameter vs. distance from snout to base of mental barbel.

osseous dorsomedial groove absent. Parietosupraoccipital process variable, narrow to wide, with margins slightly convex or moderately wide, with pronounced convex margins, always with a conspicuous constriction at base. Nuchal plate crescent-shaped, relatively short and wide.

Body and fins. Body significantly wider than high in pectoral girdle area, progressively compressed from pectoral fin to caudal peduncle. Lateral line sloping ventrally in anterior third, extending posteriorly to caudal peduncle, curving abruptly onto dorsal lobe of caudal fin. Dorsal-fin spine moderately long and thick; anterior margin with conspicuous granules along entire length, more apparent on basal two-thirds; posterior margin with serrations on distal two- thirds; lateral margin rugose in anterior half. Seven soft rays in dorsal fin. Pectoral-fin spine moderately long and very depressed, as long as dorsal-fin spine; anterior margin with granules on basal two-thirds, distal one-third smooth; posterior margin straight on basal one-fourth, distal threefourths with conspicuous serrations; dorsal margin rugose. Ten to 12 soft rays in pectoral fin. Lateral face of cleithrum wide and rugose, with posterior process indistinct and profile straight. Pelvic fin deep and short at base, with six rays. Adipose fin low, with base as long as anal fin base. Anal fin low and relatively short at base, with 16-19 rays and ventral profile concave. Caudal peduncle low. Caudal fin forked, dorsal and ventral lobes moderately long, posteriorly pointed; dorsal lobe somewhat longer than ventral lobe. 


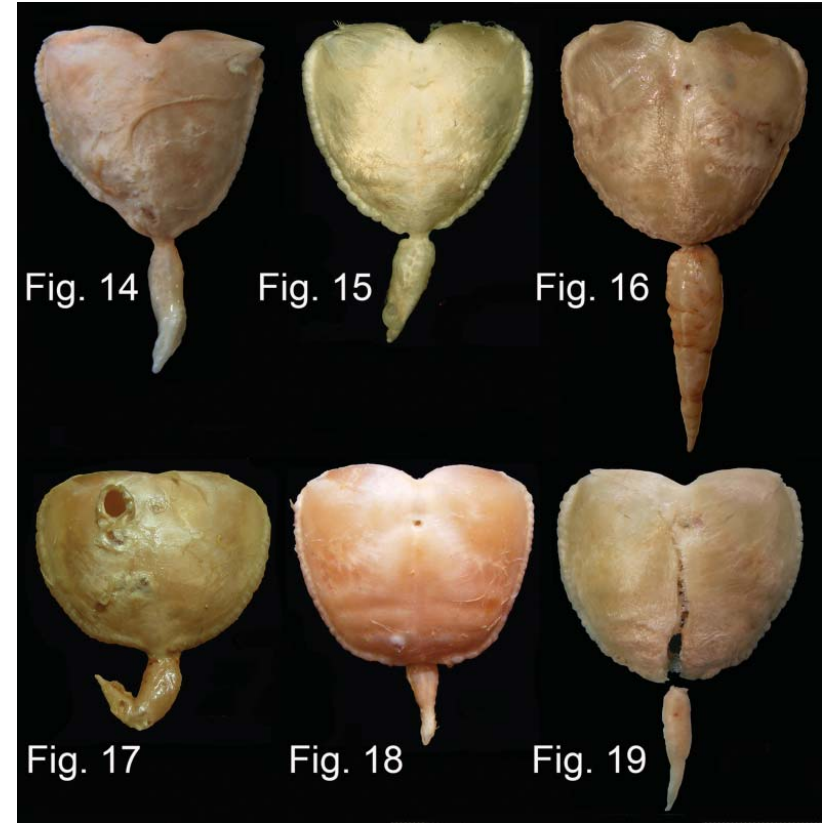

Figs. 14-19. Gas bladders in ventral view. 14. Notarius grandicassis, 193 mm SL, Salinas, Pará, Brazil, (AZUSC 4576). 15. Notarius grandicassis, 252 mm SL, Salinas Pará, Brazil, (AZUSC 4576), 16. Notarius grandicassis, $407 \mathrm{~mm}$ SL, Salinas Pará, Brazil, (AZUSC 4573). 17. Notarius parmocassis, $151 \mathrm{~mm}$ SL, Espírito Santo, Brazil, (MZUSP 10092). 18. Notarius parmocassis, 166 mm SL, Rio de Janeiro, Brazil, (MZUSP 48950). 19. Notarius parmocassis, 331 mm SL, Caerá, Brazil, (AZUSC 4612).

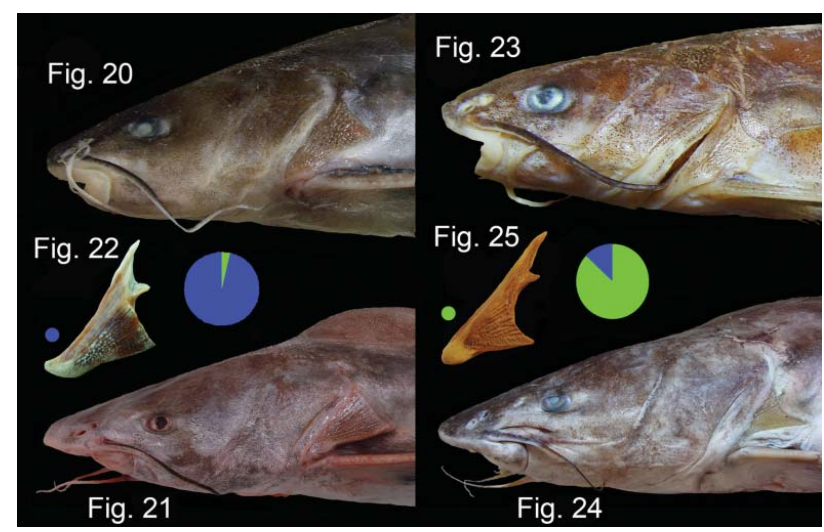

Figs. 20-25. Head and humeral process in lateral view, with pie chart showing the contribution of the different conditions, in Notarius grandicassis, shown in blue $(\mathrm{n}=33)$ and Notarius parmocassis, shown in green $(\mathrm{n}=30) .20$. Notarius grandicassis, 204 mm SL, Salinas, Pará (AZUSC 4576). 21. Notarius grandicassis, 407 mm SL, Salinas, Pará (AZUSC 4573). 22. Notarius grandicassis, $450 \mathrm{~mm} \mathrm{SL}$, Salinas, Pará (MPEG 30647). 23. Notarius parmocassis, $127 \mathrm{~mm}$ SL, Caravelas, Bahia (MZUSP 61341). 24. Notarius parmocassis, $572 \mathrm{~mm}$ SL, Vitória, Espírito Santo (AZUSC 4550). 25. Notarius parmocassis, $250 \mathrm{~mm} \mathrm{SL}$, Santos, São Paulo (MZUSP 51705).

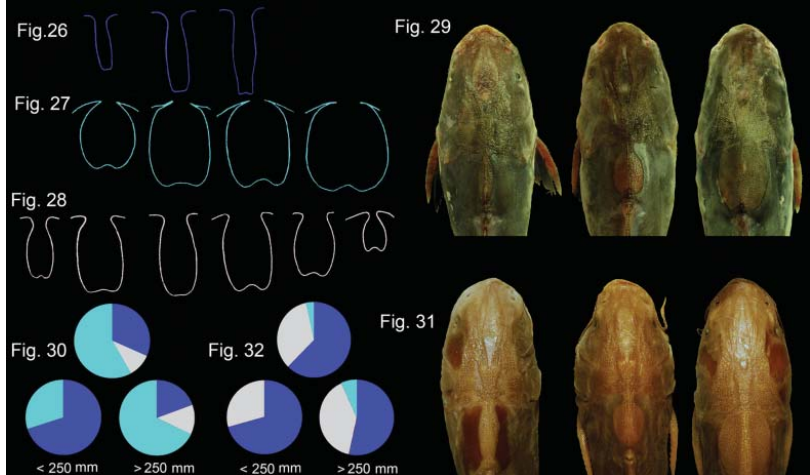

Figs. 26-32. Pattern of variation of the parietosupraoccipital process. 26. Arius grandicassis sensu C. H. Eigenmann (1912). 27. Arius parmocassis sensu C. H. Eigenmann (1912). 28. Arius stricticassis sensu C. H. Eigenmann (1912). 29. Notarius grandicassis from northeastern South America. 30. Variation in the parietosupraoccipital process in Notarius grandicassis, with upper pie chart showing the contribution of the different conditions to all specimens examined $(n=41)$, and below the contribution of the different conditions to the smaller and larger specimens. 31. Notarius parmocassis from eastern and southern Brazil. 32. Variation in the parietosupraoccipital in Notarius parmocassis, with upper pie chart showing the contribution of the different conditions to all specimens examined $(n=30)$, and below the contribution of the different conditions to the smaller and larger specimens.

Colouration. Mostly greyish brown or yellowish brown above, lighter below, yellow fins in Colombia, Venezuela, Guianas. The body was blackish, and the barbels and fins black in all ontogenetic stages in the specimens from the northern coast of Brazil.

Sexual dimorphism. Sexual dimorphism was observed in three morphological features in seven females (204$445 \mathrm{~mm} \mathrm{SL}$ ) and 19 males (184-423 mm SL). Females had higher bodies, a longer adipose fin base, and a higher pelvic fin (Table S1, see supplemental material online).

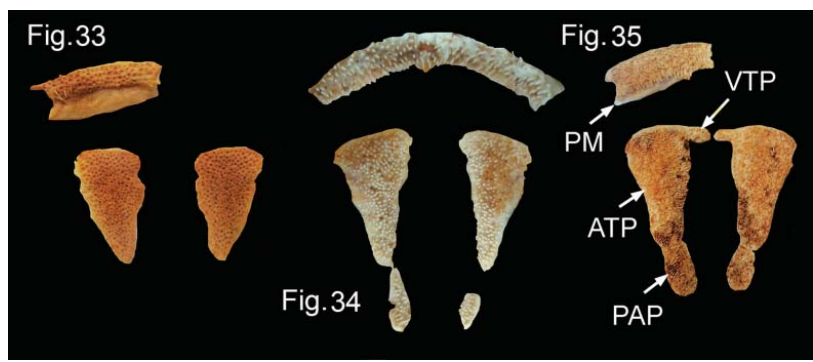

Figs. 33-35. Premaxilla, vomerine and accessory tooth plates. 33. Notarius parmocassis, $250 \mathrm{~mm}$ SL, Santos, São Paulo (MZUSP 51705). 34. Notarius grandicassis, $310 \mathrm{~mm} \mathrm{SL}$, Bragança, Pará, Brazil (MPEG uncatalogued). 35. Notarius grandicassis, $450 \mathrm{~mm}$ SL, Bragança, Pará, Brazil (MPEG 30647). ATP, accessory tooth plates; PM, premaxilla; PAP, posterior accessory tooth plates; VTP, vomerine tooth plates. 


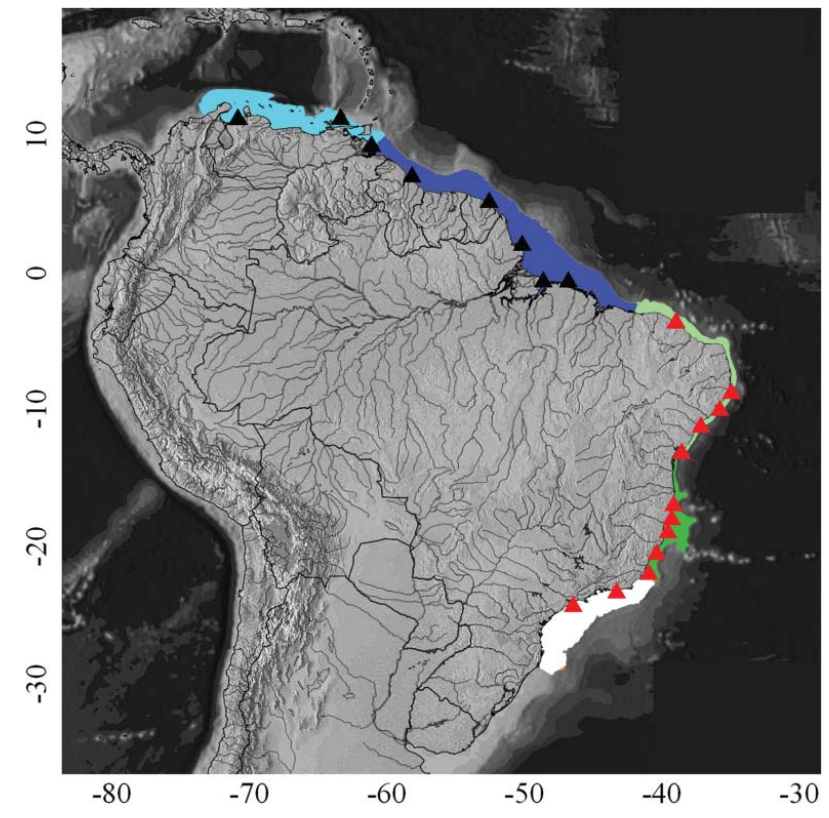

Fig. 36. Geographic distribution of the localities at which the material examined in the present study was collected: Notarius grandicassis (black triangles) and Notarius parmocassis (red triangles). Colombian and Venezuelan Caribbean (light blue), region dominated by the plume of the Amazon and Orinoco rivers, including northern Brazilian coast (dark blue), northeastern Brazilian coast (light green), eastern Brazilian coast (dark green), southern Brazilian coast (white). Note that some symbols coincide with more than one locality or a large number of specimens.

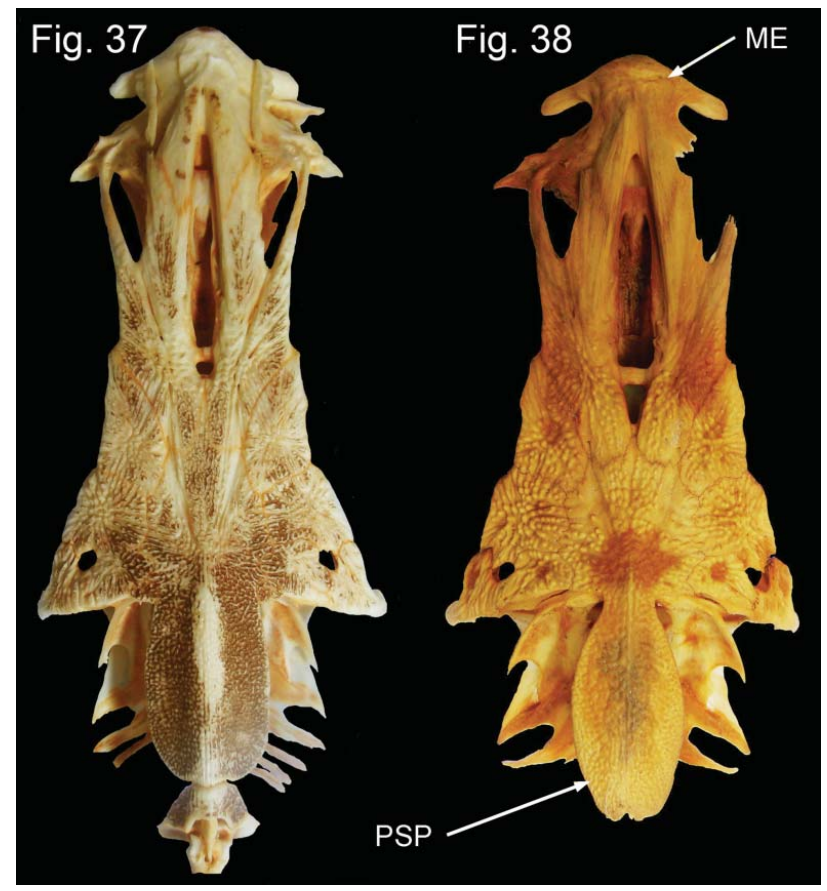

Figs. 37-38. Neurocranium in dorsal view. 37. Notarius grandicassis, 450 mm SL, Bragança, Pará, Brazil (MPEG 30618). 38. Notarius parmocassis, $250 \mathrm{~mm}$ SL, Santos, São Paulo, Brazil (MZUSP 51705). ME, mesethmoid; PSP, parietosupraoccipital process.
Table 2. Meristic frequencies of gill rakers to Notarius grandicassis and Notraius parmocassis.

\begin{tabular}{lccccccc}
\hline & $\mathbf{1 3}$ & $\mathbf{1 4}$ & $\mathbf{1 5}$ & $\mathbf{1 6}$ & $\mathbf{1 7}$ & $\mathbf{1 8}$ & $\mathbf{1 9}$ \\
\hline First arch & & & & & & & \\
Notarius grandicassis & 1 & 3 & 11 & 5 & & & \\
Notarius parmocassis & & 6 & 7 & 5 & & & \\
Second arch & & & & & & & \\
Notarius grandicassis & & & & 2 & 7 & 10 & 1 \\
Notarius parmocassis & & 1 & 5 & 10 & 2 & & \\
\hline
\end{tabular}

Morphological variation. A significant amount of variation was found in the morphology of Notarius grandicassis, with body size (SL) ranging from $184 \mathrm{~mm}$ to $445 \mathrm{~mm}$ SL, with negative or positive allometry being observed in 13 of the 41 characters examined (Table S1, see supplemental material online). The smaller specimens present a relatively shorter anterior portion of the body in comparison with the larger ones, as indicated by the head length, the distance between the snout and the pectoral and dorsal fins, and the distance between the snout and the posterior margin of the cranial fontanelle (Table S1, see supplemental material online). The snout is shorter and the barbels are smaller in larger specimens, and the lobes of the caudal fin are proportionally shorter (Table S1, see supplemental material online). The pelvic fin is proportionally longer in larger specimens, reflecting the difference between males and females (Table S1, see supplemental material online), while the parietosupraoccipital process is proportionally longer in larger specimens, reflecting the variation observed during ontogenetic development (see below).

The parietosupraoccipital process presents three distinct patterns related to ontogenetic development: (pattern 1) parietosupraoccipital process narrow with slightly convex edges, was observed in $70 \%$ of the specimens smaller than $250 \mathrm{~mm}$ SL (Figs 26, 30); in the other $30 \%$ of these smaller specimens, the process is much wider (pattern 2), and has slightly convex edges (Figs 27, 30). In specimens larger than $250 \mathrm{~mm} \mathrm{SL}$, pattern 1 was observed in $12.9 \%$ of the specimens, and pattern 2 in $67.7 \%$. In the other $12.9 \%$ of these specimens, a third, intermediate pattern (pattern 3) was recorded, characterized by a parietosupraoccipital process of intermediate width and markedly convex edges (Figs 28, 30). The thickness of the granulation of the cephalic shield and the parietosupraoccipital process also vary in accordance with the form of the parietosupraoccipital process. In the standard (pattern 1: Fig 26) and intermediate pattern (pattern 3: Fig 28), the granulation is thicker and non-uniform (Fig. 29), whereas in pattern 2 (Fig. 27), the granulation is finer and distributed more uniformly (Fig. 29). One other characteristic of the bony skeleton that differentiates smaller specimens from larger ones is the granulation of the lateral face of the cleithrum. In smaller specimens $(<250 \mathrm{~mm} \mathrm{SL})$, the 
lateral face of the cleithrum is highly granulated, with granules distributed randomly (Fig. 20). In larger specimens (> $250 \mathrm{~mm} \mathrm{SL}$ ), the granules tend to form very conspicuous grooves (Fig. 21-22).

The vomerine and accessory tooth plates also present significant variation in specimens of different sizes (Fig. 33-35). In smaller specimens ( $<250 \mathrm{~mm} \mathrm{SL})$, tooth plates associated with the vomer are generally absent or discreet vomerine plates are present, and posterior accessory plates are generally absent. In larger specimens (> $250 \mathrm{~mm} \mathrm{SL}$ ), posterior accessory and vomerine plates are typically present.

The gas bladder also varies significantly among individuals at different stages of ontogenetic development (Fig. 14 16). In smaller specimens $(<250 \mathrm{~mm} \mathrm{SL})$, the anterior chamber is longer than wide, with posterior edge sharply pointed, while the posterior chamber is greatly reduced in size in comparison with the anterior chamber (Fig. 14-15). In larger specimens (> $250 \mathrm{~mm} \mathrm{SL}$ ), however, the anterior chamber is as long as it is wide, with posterior edge moderately pointed, while the posterior chamber is significantly longer than the anterior chamber (Fig. 16).

Maximum length. According to Cervigón et al. (1992), maximum size (TL) is $630 \mathrm{~mm}$, but lengths of up to $400 \mathrm{~mm}$ SL are most common (Betancur-R. et al., 2015). In the present study, the longest standard length recorded was $445 \mathrm{~mm}$.

Distribution and abundance. This species is common in shallow waters (up to $35 \mathrm{~m}$ deep) on muddy and rocky bottoms of the north-east coast of South America (Fig. 36 ), but not estuarine environments. Notarius grandigassis is caught in warm $\left(26-29^{\circ} \mathrm{C}\right)$ and shallow $(7-25 \mathrm{~m}$ depth) waters off the Amazon coast, with salinity ranging 0.3 to 36.5. Surveys of stocks conducted in the summer and winter periods of 1996-1997 showed that N. grandicassis was the most abundant ariid in the mouth of the Amazon, in the area between latitudes $2^{\circ} 30^{\prime} \mathrm{N}$ and $0^{\circ} 5^{\prime} \mathrm{N}$, at depths of 5-50 m (JICA, 1998).

Pressure from fisheries. Notarius grandicassis is taken as bycatch by piramutaba (Brachyplatystoma vaillantii) and pink-shrimp fisheries, at depths of between 11-78 m off Pará state (Brazil), with a mean estimated CPUE of $0.51 \mathrm{~kg} /$ hectare in northern Brazil (Fredóu \& Asano-Filho, 2006). The average total catch in Pará from 1997 to 2003 was $807.51 \mathrm{t}$ (Betancur-R. et al., 2015). The stocks were estimated by area swept using the haul method, with estimates varying by season, ranging between 7409 to 17,795 t or $15-24 \%$ of total stocks (JICA, 1998). Compared with other ariid species, $N$. grandicassis is of reduced commercial significance, representing only $5 \%$ of the total catch of this group of catfish in 2006 (IBAMA, 2008).
Genetic divergence. Our results revealed the absence of genetic differentiation between Notarius grandicassis and $N$. parmocasis (Fig. 5), possibly indicating a recent speciation process with rapid morphological differentiation in distinct ecoregions of the South American Atlantic (see more in Discussion).

Remarks. Notarius grandicassis was described by Valenciennes in Cuvier \& Valenciennes (1840), based on one specimen collected in Guyana (Figs 1, 7). The original description of the species refers to characteristics typical of the Notarius grandicassis species group sensu Taylor and Menezes (1977). We consider this species to be valid based on small eye and longer snout, with the orbital diameter 3.8 in snout length (vs. 2.4-3.4 in N. parmocassis, Fig. 11 right).

Arius striticassis was described by Valenciennes in Cuvier and Valenciennes (1840), based from two specimens collected in Cayenne, French Guiana MNHN A-9406 (Figs 3, 8) and Suriname, RMNH 3034, that were diagnosed on the basis of the configuration of the parietosupraoccipital process, from which the species name is derived. The synonymy of this species is difficult to confirm due to the impossibility of obtaining morphometric data from the taxidermized type. Despite the fact that the profile of the second dorsal and posterior processes of the cleithrum of Arius striticassis is typical of Notarius parmocassis. Arius striticassis synonymy is based only on its occurrence within the known distribution area of $N$. grandicassis.

While Valenciennes (Cuvier \& Valenciennes, 1840) did not refer explicitly to the presence or absence of posterior accessory or vomerine plates in the Notarius grandicassis and Arius striticassis, Eigenmann (1912) considered these characteristics fundamental to the diagnosis of these nominal species. Eigenmann (1912) described the presence of vomerine teeth in adult $N$. grandicassis, and triangular palatine plates that project backwards. There are four plates in the adult, the two additional ones being placed just behind the two triangular ones. Eigenmann (1912) defined $N$. parmocassis by the absence of palatine tooth plates, with only two triangular palatine plates, and $N$. stricticassis by the absence of both teeth on the vomer and additional posterior patches behind the two triangular accessory tooth plates. Based on the configuration of the accessory tooth plates, Puyo (1936) described Arius vandeli based on a single specimen from the Cayenne River, in French Guiana, MNHN 1936-0160 (Figs 4, 9), diagnosed through the accessory tooth plates with a concavity. We consider Arius vandeli to represent a junior synonym of $N$. grandicassis, based on the small eyes and longer snout, with the orbital diameter 3.9 times the snout length (vs. 2.4-3.4 in N. parmocassis, Fig 11 right).

Notarius parmocassis (Valenciennes, 1840)

Bagre ariaçú, north-east coast of Brazil, Portuguese 
Bagre papai, southern coast of Brazil, Portuguese (Figs 2, 10, 17-19, 23-25, 31, 38; Table 2, 4, see supplemental material online)

Arius parmocassis Valenciennes in Cuvier and Valenciennes, 1840: 57 [original description, Bahia, Brazil].

Diagnosis. Notarius parmocassis can be distinguished from all other Neotropical ariids, except $N$. grandicassis, by the constriction at the base of the parietosupraoccipital process ( $v s$. no constriction in all other Ariidae, Figs 2, 31); pectoral-fin spine very depressed, its height at least three times its width ( $v s$. slightly to moderately depressed, always less than three times the width in all other Ariidae); gas bladder with two chambers ( $v s$. a single chamber in all other Ariidae, or three chambers in Sciades proops and S. parkeri, Fig. 17-19).

Notarius parmocassis is distinguished from Notarius grandicassis by a combination of osteological, morphometric, and meristic characters (Fig. 6). Notarius parmocassis differs from Notarius grandicassis by having 1416 or rarely 17 gill rakers on the second arch (vs. 17-19, rarely 16, Table 2); orbital diameter 2.4-3.4 times snout length (vs. 3.6-4.4, rarely 3.5, Fig. 11); lateral face of cleithrum moderately wide, with posterior profile smoothly convex or angled, ( $v s$. very wide, with posterior profile straight, Fig. 23-25). Juveniles and smaller specimens (SL $<250 \mathrm{~mm}$ ) of Notarius parmocassis can be differentiated by the relatively shorter snout, 8.0-9.6\% SL (vs. 9.7-11.0\%, Fig. 12), and the anterior chamber of the gas bladder, which is wider than it is long, with posterior edge rhomboid ( $v s$. longer than wide, with posterior edge pointed, Fig. 14-19), whereas the orbital diameter in the adults, or specimens longer than $250 \mathrm{~mm} \mathrm{SL}$, is 2.9-3.2 the distance from the snout to the base of the external mental barbel (vs. 3.3-4.1, Fig. 13), and the posterior chamber of the gas bladder is shorter than the preceding chamber (vs. longer than the previous chamber, Fig. 19).

Material examined. AZUSC 4612 (1, $331 \mathrm{~mm} \mathrm{SL),}$ Ceará, Brazil; MNRJ 20616 (1, 246 mm SL), Ceará, Brazil; CAS-SU 53483 (1), Pernambuco, Brazil; CAS-SU 53462 (1), Pernambuco, Brazil; MFAL 1822 (1, 220 mm SL), Alagoas, Brazil; AZUSC 4703 (1, 285 mm SL), Sergipe, Brazil; MNRJ 21158 (1, $305 \mathrm{~mm} \mathrm{SL})$, possibly Itaparica, Salvador, Bahia, Brazil; MNRJ 11235 (1, 446 mm SL), Madre Deus, Bahia, Brazil; MZUSP 61341 (1, 127 mm SL), Caravelas, Bahia, Brazil; MZUSP 60889 (1, $178 \mathrm{~mm}$ SL), Abrolhos, Corumbau, Bahia, Brazil; AZUSC 4550 (1, $572 \mathrm{~mm} \mathrm{SL),} \mathrm{fish} \mathrm{market,} \mathrm{Vitória,}$ Espírito Santo; CIUFES 3195 (2, 122-132 mm SL), Barra nova, São Matheus. Espírito Santo, Brazil; MZUSP 10092 (5, 108-268 mm SL), between São Matheus and Rio Doce, Espírito Santo, Brazil; MNRJ 21156 (1, 135 mm
SL), Cabo de São Tomé, Rio de Janeiro, Brazil; MZUSP 48950 (1, 166 mm SL), Cabo de São Tomé, Rio de Janeiro, Brazil; MZUSP 22773 (1, 137 mm SL), Atafona, Rio de Janeiro, Brazil; MNRJ 6429 (1, 302 mm SL), fish market, Rio de Janeiro, Brazil; MNRJ 6723 (1, 205 mm SL), fish market, Rio de Janeiro, Brazil; MNRJ 6429 (3, 302-471 mm SL), fish market, São Paulo, Brazil; MNRJ 7158 (1, 295 mm SL), fish market, São Paulo, Brazil; MNRJ 21160 (1, 266 mm SL), fish market, Santos, São Paulo, Brazil; MZUSP 51705 (1), fish market, Santos, São Paulo, Brazil.

\section{Description}

Morphometrics data. Summarized in Table S2 (see supplemental material online).

Head. Head long, moderately wide and high, markedly depressed in lateral ethmoid area, profile gently elevated posteriorly, straight from mesethmoid to parietosupraoccipital. Snout long and pointed anteriorly. Anterior nostril round, with fleshy edge, posterior nostril covered by flap of skin; nostrils distant from one another and distant from orbit, not connected by fleshy groove. Eye lateral, small and distant from one another. Three pairs of long teretiform barbels; maxillary barbel surpassing or not membranous portion of operculum, lateral mental barbel reaching or not posterior margin of gill membrane; and mesial mental barbel not reaching margin of gill membrane.

Mouth, tooth plates and gill rakers. Mouth inferior and wide, with lower jaw pronouncedly arched, and lips thick. Vomerine tooth plates absent or present. Accessory tooth plates triangular, with or without posterior plates, and sharp teeth. Premaxilla moderately long and wide, with sharp teeth. Dentary tooth plates separated at midline, with sharp teeth. Gill membranes fused together and attached to isthmus. Fourteen to 16 acicular gill rakers on first arch, 14-17 spike-shaped gill rakers on second arch.

Neurocranium. Cephalic shield exposed, long and wide in lateral ethmoid area, moderately wide in frontal and supracleithrum areas, with dense granulation irregularly distributed or fine granulation uniformly distributed. Osseous bridge formed by lateral ethmoid and frontal relatively long and slender, delimiting a moderately large fenestra, evident under skin. Fleshy dorsomedial groove of neurocranium evident at level of mesethmoid to frontal, with posterior osseous dorsomedial groove absent. Parietosupraoccipital process very variable, narrow to wide, with lateral margins slightly to pronouncedly convex, always with conspicuous constriction at base. Nuchal plate crescent-shaped, relatively long and wide. 
Body and fins. Body significantly wider than high in pectoral girdle area, progressively compressed from pectoral fin to caudal peduncle. Lateral line sloping ventrally in anterior third, extending posteriorly to caudal peduncle, curving abruptly onto dorsal lobe of caudal fin. Dorsal-fin spine moderately long and thick; anterior margin with small conspicuous granules along entire length, though more apparent on basal two-thirds; posterior margin with conspicuous serrations on distal two-thirds; lateral margin with rugose anterior half. Seven soft rays in dorsal fin. Pectoral-fin spine moderately long and very depressed, as long as dorsal-fin spine; anterior margin with granules on basal two-thirds and smooth on distal third; posterior margin straight on basal one-fourth, distal three-fourths with conspicuous serrations; dorsal margin rugose. Ten to 11 soft rays in pectoral fin. Lateral face of cleithrum moderately wide and rugose, with posterior process distinct and posterior profile concave, especially in adult specimens. Pelvic fin deep and short at base, with six rays. Adipose fin low, with base as long as anal fin base. Anal fin low and relatively short at base, with 1719 rays and ventral profile concave. Caudal peduncle low. Caudal fin forked, dorsal and ventral lobes moderately long, posteriorly pointed; dorsal lobe somewhat longer than ventral lobe.

Colouration. Mostly greyish brown or yellowish brown above, lighter below, yellow fins.

Sexual dimorphism. Sexual dimorphism was observed in nine morphological features in seven females (166$246 \mathrm{~mm} \mathrm{SL}$ ) and 19 males (127-471 mm SL) (Table S2, see supplemental material online). Females have wider heads, as indicated by the interorbital distance, the width of the cephalic shield in the lateral ethmoid region. Females also have a longer supraoccipital process and a greater snout to dorsal-fin distance. The females also have a longer pelvic fin and longer pectoral spine. Males present longer distance from snout to pelvic fin and a longer adipose fin base.

Morphological variation. Significant variation is found in the development of Notarius parmocassis in the size range from $108 \mathrm{~mm}$ to $572 \mathrm{~mm} \mathrm{SL}$, expressed by negative or positive allometry in 17 of the 42 characters examined (Table S2, see supplemental material online). Smaller specimens $(<250 \mathrm{~mm} \mathrm{SL})$ have significantly larger eyes, longer caudal fin lobes, longer barbels and longer adipose fin base. In larger specimens ( $>250 \mathrm{~mm} \mathrm{SL}$ ), the anterior portion of the head and body are relatively longer, as indicated by the longer head and snout, and the greater distances from snout to mental barbels, and the snout and the dorsal fin. The pelvic fin is longer in adults, reflecting the variation between males and females (Table S2, see supplemental material online), while the parietosupraoccipital process is longer in larger specimens, reflecting ontogenetic variation (see below). Larger specimens also have a longer pectoral-fin spine and greater interorbital distance.

The narrow parietosupraoccipital process, with slightly convex or almost parallel edges (pattern 1) was observed in $62.1 \%$ of the specimens examined (Figs 28, 32), and found in $71.4 \%$ of the smaller specimens $(<250 \mathrm{~mm} \mathrm{SL})$, and $53.3 \%$ of the specimens larger than $250 \mathrm{~mm} \mathrm{SL}$ (Figs 26, 32). Pattern 2 (wide parietosupraoccipital process with slightly convex edges) was observed in only one specimen, representing $3.4 \%$ of the total (Figs 27, 32). The intermediate condition (pattern 3), characterized by a parietosupraoccipital process with a wide basal constriction and highly convex lateral edges, was observed in $34.5 \%$ of the specimens examined, and was more common in specimens larger than $250 \mathrm{~mm}$ SL (Figs 28, 32). In patterns 1 and 3, the granulation is thicker and more irregular, while in pattern 2 , it is finer and distributed more uniformly (Fig. 31). One other important feature of the bony skeleton is the granulation of the lateral face of the cleithrum (Fig. 23-25), which is more intense and irregular in smaller specimens (Fig 23), whereas the granules form conspicuous grooves in larger specimens (Fig. 2425).

Accessory and vomerine tooth plates also varied significantly in specimens of different sizes (Fig. 33-35). Vomerine plates were generally absent or inconspicuous in smaller specimens, and posterior accessory plates are absent. Large specimens have both vomerine and posterior accessory plates. Distinct intermediate patterns can also be found between these two stages. Ontogenetic variation is also found in the gas bladder, which shows the anterior chamber relatively longer in larger specimens (Fig. 17-19).

Maximum length. The largest specimen recorded was caught in Espirito Santos state, with $572 \mathrm{~mm}$ SL.

Distribution and abundance. This species is not common on the north-east $\left(3^{\circ} \mathrm{N}\right.$ to $\left.13^{\circ} \mathrm{N}\right)$ and southern Brazilian coasts $\left(22^{\circ} \mathrm{N}\right.$ to $\left.28^{\circ} \mathrm{N}\right)$, but is relatively more abundant on the east coast $\left(13^{\circ} \mathrm{N}\right.$ to $\left.22^{\circ} \mathrm{N}\right)$ (Fig. 36). Juvenile specimens were observed only in Espírito Santo. In samples collected from industrial catches landed in São Paulo state between May 1991 and November 1994, 1,479 ariid specimens were identified, including only 15 Notarius parmocassis specimens (345-420 mm SL), captured over muddy bottoms at depths of between 28 and 30 metres in the area between Bom Abrigo and Paranaguá $\left(25^{\circ} 00^{\prime} \mathrm{S}\right.$ to $\left.25^{\circ} 30^{\prime} \mathrm{S}\right)$.

Pressure from fisheries. The species is captured as bycatch by shrimp trawlers in the Peruipe River, southern Bahia, and in São Vicente, and São Paulo (Graca-Lopes, 
Tomas, Tutui, Rodrigues, \& Puzzi, 2002; SarmentoSoares, Mazzoni, \& Martins-Pinheiro, 2007).

Genetic divergence. Our results revealed the absence of genetic differentiation between Notarius parmocasis and $N$. grandicassis (Fig. 5), possibly indicating a recent speciation process with rapid morphological differentiation in distinct ecoregions in the Atlantic South America (see Discussion).

Remarks. Notarius parmocassis was described by Valenciennes in Cuvier and Valenciennes (1840), based on a single specimen (MNHN A-8966) collected in Bahia, Brazil (Figs 2, 10). The species was defined based on the configuration of the parietosupraoccipital process, Arius a casque en bouclier. In the original description, the authors draw a number of comparisons, and highlight the accessory tooth plates, which form an angle, possibly due to the presence of vomerine plates, the shorter snout and the relatively larger eye in comparison with the snout, thicker granulation of the cranium, and more robust, rugose cleithrum in comparison with $N$. grandicassis (see Valenciennes, in Cuvier \& Valenciennes, 1840). Although characteristics of the type specimen, such as the profile of the cleithrum, contrast with the typical pattern observed in $N$. parmocassis, the nominal species is considered valid on the basis of its relatively large eyes and shorter snout, with orbital diameter 2.8 in snout length (vs. 3.5-4.4 in $N$. grandicassis, Fig. 11 right), as described by Valenciennes (1840).

\section{Discussion}

\section{Species limits and definition}

The categorization and naming of a species should be regarded as a hypothesis on the evolutionary relationships and distinguishability of different groups of organisms (Costa-Silva, Rodriguez, Roxo, Foresti, \& Oliveira, 2015). As the speciation process progresses, boundaries between species become increasingly evident, but when it is incipient, at a point known as the grey zone, the boundaries between the species may be difficult to identify, and are very subjective (De Queiroz, 2007). Mitochondrial DNA sequences have been used to distinguish closely related species in recent studies (Benine, Mariguela, \& Oliveira, 2009; Melo, Benine, Mariguela, \& Oliveira, 2011; Menezes, Nirchio, Oliveira, \& Siccha-Ramirez, 2015). By contrast, there are far fewer studies that have failed to differentiate between two or more species of a given genus or different genera using mitochondrial markers (Avelino, Britski, Foresti, \& Oliveira, 2015; Costa-Silva et al., 2015; Roxo, Costa-Silva, \& Oliveira, 2015; Shirak et al., 2009).

The different approaches used to identify species boundaries and characterize independent evolutionary units using morphological and molecular data have been evaluated by Costa-Silva et al. (2015), who concluded that species limits do not appear in a fixed order. Based on an integrative taxonomic approach (morphological, mixed Yule-coalescent and BOLD system analyses), these authors recognized 73 OTUs in a group of Neotropical freshwater fish with a long and problematic taxonomic history and pronounced morphological similarities among the species (genus Rineloricaria Bleeker, 1862). In this analysis, $41 \%$ of the species coincided with their genetic and morphological definitions, while $26 \%$ were morphospecies not discriminated by the molecular analysis, and $33 \%$ were recognized only in the molecular analysis.

Costa-Silva et al. (2015) consider morphospecies with little or no genetic divergence to be the result of a speciation process that has yet to reach reciprocal monophyly, with levels of genetic divergence equivalent to that found among populations of a single species. In this context, morphospecies are always isolated in distinct or unconnected ecoregions, reflecting a recent vicariant process followed by rapid morphological differentiation (Bellafronte, Mariguela, Garcia-Pereira, Oliveira, \& MoreiraFilho, 2013).

\section{Ecoregions and evolutionary lineages on the Atlantic coast of South America}

The lack of genetic differentiation between Notarius grandicassis and N. parmocassis, despite the existence of morphological differences, is interpreted here as a consequence of the evolutionary history of these species, which are found in different geographic areas with distinct environmental conditions (da Silva et al., 2016). However, little is known of the differentiation of the coastal and estuarine fish fauna of the Atlantic coast of South America and environmental factors that can contribute to this differentiation (see Santos, Hrbek, Farias, Schneider, \& Sampaio, 2006; da Silva et al., 2016). The study of da Silva et al. (2016) is one important contribution, which recognized the existence of two distinct genetic and morphological lineages of Bagre bagre (sensu Acero, 2003), with an estimated age of $1.8 \mathrm{my}$, on the Atlantic coast of South America. The differentiation of these lineages has been attributed to the glacial cycles of the early Pleistocene, with salinity and other environmental variables that characterize the area between the Amazon-Orinoco plume and the north-eastern extreme of Brazil being identified as the principal factor determining the current isolation of these, as for the other ariids found on the Atlantic coast of South America (da Silva et al., 2016).

While the functional and ecological implications of morphological differences are difficult to interpret, it seems reasonable to assume that the phenotypic traits differentiating Notarius grandicassis and $N$. parmocassis are 
adaptive. The relatively small eyes in smaller specimens ( $<250 \mathrm{~mm} \mathrm{SL})$ of $N$. grandicassis may be related to the turbidity of the water in the area where the species occurs, i.e., the Atlantic plume, in contrast with the larger-eyed $N$. parmocassis, found primarily on the north-eastern and eastern coasts of Brazil, which have much clearer waters, as in the Caribbean. Similarly, the differences in the size of the posterior chamber of the gas bladder may be associated with differences in the salinity in the two regions, as well as behaviour patterns, with $N$. grandicassis being common at depths of up to 50 metres on the northern continental shelf, but only $30 \mathrm{~m}$ off the southern coast. Environmental differences related to feeding habits may be associated with the development of the snout in $N$. grandicassis (see mesethmoid in Fig. 37-38). The main food items on the northern coast are crustaceans and gobiid fishes (Mendes \& Barthem, 2010), where the snout may play an important role in foraging in the muddy substrate, in contrast to Brazilian north-eastern and eastern coasts, where muddy substrates are rare. Unfortunately, the genetic determinants of these morphological differences are not known.

In this scenario, adaptive geographic variation in the phenotypes represents the first step toward genetic divergence (Herrell, Meyers, \& Vanhooydonck, 2001) and phenotypic plasticity is initially favoured over adaptive genetic divergence (Alpert \& Simms, 2002; Schlichting, 2004; Zhivotovsky, Feldman, \& Bergman, 1996), with the genes involved in morphological differentiation changing faster than neutral or non-adaptive genes, which may vary later in the process (Skúlason, Snorrason, \& Jónsson, 1999; Wimberger, 1994; West-Eberhard, 2003, 2005). The different patterns of variation of the supraoccipital process in N. grandicassis and N. parmocassis (Fig. 2632 ), provides additional evidence of the incipient speciation process, which is initiated, but not completed, by divergent selection.

The influence of the environmental conditions found along the Atlantic coast of South America on the differentiation of closely related lineages (da Silva et al., 2016) or incipient species also appear to be responsible for the pattern of morphological variation observed in Aspistor quadriscutis (Valenciennes, 1840) and A. luniscutis (Valenciennes, 1840), two species that are well-defined morphologically (Marceniuk \& Menezes, 2007), but have diverged very recently, in molecular terms, less than one million years ago (Betancur-R, 2009), with patterns of morphological differentiation highly similar to those observed in Notarius grandicassis and N. parmocassis, such as the size of the eye, the format of the occipital process, and nuchal plate (Marceniuk, in preparation). There is a similar lack of molecular evidence (Betancur-R., 2009) supporting the recognition of Cathorops spixiii (Agassiz, 1829) and C. arenatus (Valenciennes, 1840), from north-eastern South America, and Genidens barbus
(Lacepède, 1803) and G. machahoi (Miranda Ribeiro, 1918), from the southern Atlantic, despite the well-defined morphological differentiation of these species (Marceniuk, 2005b; Marceniuk, Betancur-R., Acero, \& MurielCunha, 2012).

While the results of the present study do not provide any direct evidence of the characteristics of the isolation process that differentiated the species, we are faced with the task of disentangling to what extent the variation in morphological traits among contemporary populations can be attributable to adaptation to the current environmental conditions (parapatric speciation), or whether it is the result of recent ecological shifts or the invasion of novel habitats where adaptive divergence is strong (ecological speciation). The potential for hybridization between the species is clear, but the existence of distinct morphotypes indicates that reduced hybrid fitness may reinforce the established morphological divergence.

Independently of the discussion of 'lumpers' and 'splitters' (see Simpson, 1945), the redescription of Notarius grandicassis from north-eastern South America, and Notarius parmocassis from the eastern and southern coast of Brazil, reflects the existence of distinct evolutionary units, which are well differentiated in morphological terms, and represent a fundamental step towards the continuity of the diversity in local lineages, which are subject to distinct natural and anthropogenic pressures.

\section{Acknowledgements}

The authors are greatly indebted to Marcelo R. Britto (MNRJ-UFRJ), Matheus M. Rotundo (AZUSC), JeanCristophe Joyeux (UFES), Selma Torquato and Tami Mott (NHN-UFAL) for allowing access to the collections they curate. Matheus M. Rotundo (AZUSC), Katia Freire (UFSE), and João Luiz Rosetti Gasparini (UDES) for the collection of valuable specimens, and Tami Mott (UFAL) by transfer of tissue samples. Claudio de Oliveira (UNESP) for sequencing the molecular markers used in the present study, of the specimen collected in Brazil, generated in the Laboratory of Fish Biology and Genetics (LBP) at São Paulo State University (UNESP), at Botucatu. Sandra J. Raredon (USNM) for photographs and morphometrics of specimens from the Smithsonian Institution, Hudson Pinheiro (CAS) for photographs of specimens from the California Academy of Sciences, Décio F. Moraes Jr. (MNRJ) for photographs of specimens from the Museu Nacional do Rio de Janeiro (UFRJ), and Madlen Stange (PIMUZ) for photographs of skeletonized specimens from the Museum of the University of Zurich. We are indebted to Claudio Oliveira (UNESP) and Carl Ferraris for reading the manuscript and offering valuable suggestions and comments, and Stephen Ferrari (UFS) for reading and correcting most of the English text. Special 
thanks are due to two anonymous reviewers for their critical reading of the manuscript and their valuable suggestions and comments. This study was supported by the National Science and Technology Council of the Brazilian Federal Government (CNPq grant no. 300462/2016-6 to APM), the Pará State Research Foundation (FAPESPA grant no. ICAAF 017/2016 to APM), and CNPq (processes \#300940/2015-7 and 405144/2013-0 to WBW).

\section{Disclosure statement}

No potential conflict of interest was reported by the authors.

\section{Funding}

This work was supported by the Pará State Research Foundation [grant number ICAAF 017/2016]; National Science and Technology Council of the Brazilian Federal Government [grant number 152782/2007-9], [grant number 300940/2015-7], [grant number 300462/2016-6].

\section{Supplemental data}

Supplemental material for this article can be accessed here: http://dx.doi.org/10.1080/14772000.2016.1256916

\section{References}

Acero, P.A. (2003). Ariidae. In K. E. Carpenter (Ed.). The living marine resources of the Western Central Atlantic. Volume 2: Bony fishes part 1 (Acipenseridae to Grammatidae) 831852. FAO species identification guide for fishery purposes and American Society of Ichthyologist and Herpetologists Special Publication. No. 5. Western Central Atlantic. Volume 2. Rome: Food and Agriculture Organisation.

Alpert, P., \& Simms, E.L. (2002) The relative advantages of plasticity and fixity in different environments: When is it good for a plant to adjust? Evolutionary Ecology, 16, 285-297.

Amaral, A.C.Z., \& Jablonski, S. (2005). Conservação da biodiversidade marinha e costeira do Brasil. Megadiversidade, 1, 43-51.

Avelino, G.S., Britski, H.A., Foresti, F., \& Oliveira, O. (2015). Molecular identification of Leporinus from the south portion of South America. DNA Barcodes, 3, 98-109.

Bellafronte, E., Mariguela, T. C., Pereira, L. H. G., Oliveira, C., \& Moreira-Filho, O. (2013). DNA barcode of Parodontidae species from the La Plata river basin - Applying new data to clarify taxonomic problems. Neotropical Ichthyology, 11, 497-506.

Benine, R.C., Mariguela, T.C., \& Oliveira, C. (2009). New species of Moenkhausia Eigenmann, 1903 (Characiformes: Characidae) with comments on the Moenkhausia oligolepis species complex. Neotropical Ichthyology, 7, 161-168.

Betancur-R., R. (2009). Molecular phylogenetics and evolutionary history of ariid catfishes revisited: A comprehensive sampling. BioMedCentral Evolutionary Biology, 9, 175.

Betancur-R, R., Marceniuk, A.P., Giarrizzo, T., Fredou, F.L., \& Knudsen, S. (2015). Notarius grandicassis, Thomas Sea
Catfish. The IUCN Red List of Threatened Species, e. T197018A, 1-6.

Castro, M.P.G. (2000). Estrutura e Dinâmica da Pesca de Parelha do Estado de São Paulo e Aspectos da Biologia dos Principais Recursos Pesqueiros do Sudeste/sul do Brasil. (Structure and Dynamics of Doublet Fisheries of the State of São Paulo and Aspects of Biology Major Fisheries Resources South East / South Brasi). Ph. D. Dissertation, Brazil: Instituto Oceanográfico da Universidade de São Paulo.

Cervigón, F. (1991). Los peces marinos de Venezuela. Volumen I. 2a edición (pp. 425). Caracas: Fundación Científica Los Roques.

Cervigón, F., Cipriani, R., Fischer, W., Garibaldi, L., Hendrickx, M., Lemus, A.J.,... Rodriguez, B. (1992). Guia de campo de las especies comerciales marinas y de aguas salobres de la costa septentrional de Sur America (pp. 513). Rome: Organización de las Naciones Unidas para la Agricultura y la Alimentación.

Costa-Silva, G.J., Rodriguez, M.S., Roxo, F.F., Foresti, F., \& Oliveira, C. (2015). Using different methods to access the difficult task of delimiting species in a complex Neotropical hyperdiverse group. Public Library of Science One, 10, e0135075. doi:10.1371/journal.pone.0135075

Cuvier, G., \& Valenciennes, A. (1840). Histoire Naturelle des Poissons. Tome Quinzième. Suite du Livre Dix-septième. Paris \& Strasbourg: Siluroïdes. Ch. Pitois \& V Levrault.

da Silva, W. C., Marceniuk, A. P., Sales, J. B. L., \& Araripe, J. (2016). Early Pleistocene lineages of Bagre bagre (Linnaeus, 1766) (Siluriformes: Ariidae), from the Atlantic coast of South America, with insights into the demography and biogeography of the species. Neotropical Ichthyology, 14, e150184.

De Queiroz, K. (2007). Species concepts and species delimitation. Systematic Biology, 56, 879-886.

Eigenmann, C.H. (1912). The freshwater fishes of British Guiana, including a study of the ecological grouping of species, and the relation of the fauna of the plateau to that of the lowlands. Memoirs of the Carnegie Museum, 5, 1-578.

Ekau, W., \& Knoppers, B.A. (1999). An introduction to the pelagic system of the East and Northeast Brazilian shelf. Archive of Fishery and Marine Research, 47, 113-132.

Fredóu, F. L., \& Asano-Filho, M. (2006). Recursos Pesqueiros da Regiao Norte. REVIZEE: Avaliacao dopotencial sustentavel de recursos vivos na Zona Economica Exclusiva: relatorio executivo, 181-206. Brasilia: Ministerio do Meio Ambiente.

Figueiredo, J. L., \& Menezes, N. A. (1978). Manual de peixes marinhos do sudeste do Brasil. II. Teleostei (1). Brasil: Museu de Zoologia, Universidade de São Paulo. 110 pp.

Graça-Lopes, R., Tomás, A.R.G., Tutui, S.L.S., SeverinoRodrigues, E., \& Puzzi, A. (2002). Fauna acompanhante da pesca camaroeira no litoral do estado de São Paulo, Brasil. Boletim do Instituto de Pesca, 28, 173-188.

Herrel, A., Meyers, J.J., \& Vanhooydonck, B. (2001). Correlations between habitat use and body shape in a phrynosomatid lizard (Urosaurus ornatus): a population-level analysis. Biological Journal of the Linnean Society, 74, 305-314.

IBAMA. (2008). Estatística da pesca 2006: Grandes regiões e unidades da Federação. Brasília: Instituto Brasileiro do Meio Ambiente e dos Recursos Naturais Renováveis.

JICA (1998). Fishery resources study of the Amazon and Tocantins River mouth areas in the Federative Republic of Brazil (pp. 334). Tokyo: Sanyo Techno Marine.

Kearse, M., Moir, R., Wilson, A., Stones-Havas, S., Cheung, M., Sturrock, S.,... Drummond, A. (2012). Geneious Basic: an integrated and extendable desktop software platform for the organization and analysis of sequence data. Bioinformatics, 
28, 1647-1649. http://dx.doi.org/10.1093/bioinformatics/ bts199 (accessed 13 December 2016).

Kimura, M. (1980). A simple method for estimating evolutionary rates of base substitutions through comparative studies of nucleotide sequences. Journal of Molecular Evolution, 16, 111-120. http://dx.doi.org/10.1007/BF01731581 (accessed 13 December 2016).

Le Bail, P.Y., Keith, P., \& Planquette, P. (2000). Atlas des Poissons d'Eau Douce de Guyane. Tome 2, Fascicule II, Siluriformes. Paris: Publications scientifiques du MNHN, Service du Patrimoine Naturel.

Marceniuk, A.P. (2005a). Chave para identificação des espécies de bagres marinhos (Siluriformes, Ariidae) da costa Brasileira. Boletim do Instituto do Pesca, São Paulo, 31, 89-101.

Marceniuk, A.P. (2005b). Redescrição de Genidens barbus (Lacépède, 1803) e Genidens machadoi (Miranda-Ribeiro, 1918), bagres marinhos (Siluriformes, Ariidae) do Atlântico sul ocidental. Papéis Avulsos de Zoologia, 45, 111-125.

Marceniuk, A.P. (2007). Description of Cathorops manglarensis, a new species from the Colombian Pacific, with redescription of Cathorops multiradiatus (Siluriformes; Ariidae). Zootaxa, 1529, 33-48.

Marceniuk, A.P., \& Menezes, N.A. (2007). Systematics of the family Ariidae (Ostariophysi, Siluriformes), with a redefinition of the genera. Zootaxa, 1416, 1-126.

Marceniuk, A.P., \& Betancur-R. R. (2008). Revision of the species of the genus Cathorops (Siluriformes: Ariidae) from Mesoamerica and the Central American Caribbean, with description of three new species. Neotropical Ichthyology, 6, 25-44.

Marceniuk, A.P., Betancur-R. R., \& Acero, P.A. (2009). A new species of Cathorops (Siluriformes; Ariidae) from Mesoamerica, with redescription of four species from the eastern Pacific. Bulletin of Marine Science, 85, 245-280.

Marceniuk, A.P., Menezes, N.A., \& Britto, M.R. (2012). Phylogenetic analysis of the family Ariidae (Ostariophysi: Siluriformes), with a hypothesis on the monophyly and relationships of the genera. Zoological Journal of the Linnean Society, 165, 534-669.

Marceniuk, A.P., Betancur-R., R., Acero, A.P. \& Muriel-Cunha, J. (2012). Review of the genus Cathorops (Siluriformes, Ariidae) from the Caribbean and the Atlantic South America, with description of a new species. Copeia, 2012, 77-97.

Mejía-Ladino, L.M., Betancur-R. R., Acero, A.P., \& Zarza, E. (2002). Presencia de Arius grandicassis en el Caribe colombiano, incluyendo una clave para la dentificación de los peces de la familia Ariidae en el área. Boletín Instituto de Investigaciones Marinas y Costeras, 31, 5-13.

Melo, B.F., Benine, R.C., Mariguela, T.C., \& Oliveira, C. (2011). A new species of Tetragonopterus Cuvier, 1816 (Characiformes: Characidae: Tetragonopterinae) from the Rio Jari, Amapá, northern Brazil. Neotropical Ichthyology, 9, 49-56.

Menezes, N.A., Nirchio, M., Oliveira, C., \& Siccha-Ramirez, R. (2015). Taxonomic review of the species of Mugil (Teleostei: Perciformes: Mugilidae) from the Atlantic South Caribbean and South America, with integration of the morphological, cytogenetic and molecular data. Zootaxa, 3918, 1-38.

Mendes, F.L.S., \& Barthem, R.B. (2010). Hábitos alimentares de bagres marinhos (Siluriformes: Ariidae) do estuário amazônico. Boletim do Museu Pararense Emilio Goeldi, Belém, 5, 1-11.

Puyo, J. (1936). Contribution à l'étude ichthyologique de la Guyane française. Pêches et pêcheries. Bulletin de la Société d'Histoire Naturelle de Toulouse, 70, 5-258.
Roxo, F.F., Costa-Silva, G.J., \& Oliveira, C. (2015). Species delimitation in Neoplecostomus (Siluriformes: Loricariidae) using morphologic and genetic approaches. DNA Barcodes, $3,110-117$.

Santos, S., Hrbek, T., Farias, I. P., Schneider, H., \& Sampaio, I. (2006). Population genetic structuring of the king weakfish, Macrodon ancylodon (Sciaenidae), in Atlantic coastal waters of South America: deep genetic divergence without morphological change. Molecular Ecology, 15, 4361-4373.

Sarmento-Soares, L.M., Mazzoni, R. \& Martins-Pinheiro, R.F. (2007). A fauna do Rio Peruipe, extremo sul da Bahia. Biota Neotropica, 7, bn02107032007.

Schlichting, C.D. (2004). The role of phenotypic plasticity in diversification. In T. J. DeWitt, T., \& S. M. Scheiner (Eds). Phenotypic Plasticity: Functional and Conceptual Approaches (pp. 191-200). Oxford: Oxford University Press.

Shirak, A., Cohen-Zinder, M., Barroso, R.M., Seroussi, E., Ron, M., \& Hulata, G. (2009). DNA Barcoding of Israeli Indigenous and Introduced Cichlids. The Israeli Journal of Aquaculture-Bamidgeh, 61, 83-88.

Siccha-Ramirez, R., Menezes, N. A., Nirchio, M., Foresti, F., \& Oliveira, C. (2014). Molecular Identification of Mullet Species of the Atlantic South Caribbean and South America and the Phylogeographic Analysis of Mugil liza. Reviews in Fisheries Science \& Aquaculture, 22, 86-96.

Simpson, G. G. (1945) The principles of classification and a classification of Mammals. Bulletin of the American Museum of Natural History, 85, 1-350.

Skúlason, S., Snorrason, S.S., \& Jónsson B. (1999). Sympatric morphs, populations and speciation in freshwater fish with emphasis on Arctic charr. In A. E. Magurran \& R. May (Eds.), Evolution of biological diversity (pp. 70-92). Oxford: Oxford University Press.

Strauss, R.E., \& Bond, C.E. (1990). Taxonomic methods: morphology. In P. Moyle \& C. Schreck (Ed.). Methods for Fish Biology (pp. 109-140). Bethesda: American Fisheries Society, Special Publication.

Tamura, K., Peterson, D., Peterson, N., Stecher, G., Nei, M., \& Kumar, S. (2011). MEGA5: molecular evolutionary genetics analysis using maximum likelihood, evolutionary distance, and maximum parsimony methods. Molecular Biology and Evolution, 28, 2731-2739.

Taylor, W.R., \& Menezes, N.A. (1977). Family Ariidae. In W. Fischer (Ed.). FAO Species Identification Sheets Fishery Purposes. Western Central Atlantic (Fishing Area 31). Rome: FAO.

West-Eberhard, M.J. (2003). Developmental Plasticity and Evolution. New York: Oxford University Press.

West-Eberhard, M.J. (2005). Developmental plasticity and the origin of species differences. Proceedings of the National Academy of Sciences of the United States of America, 102, 6543-6549.

Wimberger, P.H. (1994). Trophic polymorphisms, plasticity, and speciation in vertebrates. In D. J. Stouder \& K. Fresh (Eds). Advances in Fish Foraging Theory and Ecology. Columbia, South Carolina: Belle Baruch Press.

Zhivotovsky, L.A., Feldman, M.W., \& Bergman, A. (1996). On the evolution of phenotypic plasticity in a spatially heterogeneous environment. Evolution, 50, 547-558.

Associate Editor: Kevin Conway 